\title{
Pengukuran Karakteristik Dielektrik Minyak Goreng Berdasarkan Lama Pemanasan Menggunakan Rangkaian Sederhana Multivibrator IC 555
}

\author{
Misto $^{1}$, Supriyadi $^{2}$ \\ ${ }^{1}$ Jurusan Fisika, Universitas Jember, Indonesia \\ ${ }^{2}$ Jurusan Kimia, Universitas Jember, Indonesia
}

\begin{abstract}
An electronic system for cooking oil dielectric constant measurement have been done. The system was employed an capacitive sensor, IC Timer 555, oscilloscope, and power supply. The cooking oil is placed in a capacitive sensor as part of unstable multivibrator IC 555 circuit. The samples(labeled and non labeled) temperature was condisioned on room temperature and at $100{ }^{\circ} \mathrm{C}$ with the heated time duration of 1 hours, 2 hours, and 3 hours treatment. The result of the measurement shows that all sample with time duration 1 hours and 2 hours increases but with time duration 3 hours turn down.
\end{abstract}

Keyword:Sugarcontent,Pinphotodiode,Computer

\begin{abstract}
ABSTRAK
Penelitian ini merancang sistem elektronik untuk pengukuran konstanta dielektrik minyak goreng. Sistem ini menggunakan sensor kapasitif, IC Timer 555, osiloskop, dan catu daya. Minyak goreng ditempatkan dalam sensor kapasitif sebagai bagian dari rangkaian IC 555 multivibrator yang tidak stabil. Suhu sampel (berlabel dan tidak berlabel) dikondisikan pada suhu kamar dan pada $100{ }^{\circ} \mathrm{C}$ dengan durasi waktu pemanasan 1 jam, 2 jam, dan 3 jam perlakuan. Hasil pengukuran menunjukkan bahwa semua sampel dengan durasi waktu 1 jam dan 2 jam meningkat tetapi dengan durasi waktu 3 jam menurun.
\end{abstract}

Katakunci:Sugarcontent,Pinphotodiode,Computer

\section{PENDAHULUAN}

Minyak trafo adalah cairan yang ditempatkan di dalam trafo dan turut memberikan kontribusi pada perilaku kerja sebuah transformator. Salah satu fungsi minyak trafo adalah sebagai pembuang panas dan sekaligus sebagai isolator listrik. Dalam pemilihan minyak untuk trafo, diperlukan yang bebas mineral PCB (polychlorinated biphenyl) juga diperlukan studi rinci tentang sifat dielektrik. Akhir-akhir ini terdapat usaha untuk mencari alternatif minyak trafo dari minyak nabati, seperti minyak goreng dari kelapa sawit. Nilai konstanta dielektrik minyak trafo telah ditentukan oleh Komisi Internasional Elektroteknik (nomor IEC60296 ) pada frekuensi rendah. Indonesia sebagai penghasil minyak sawit, perlu berinovasi untuk menyumbang pada penyediaan minyak trafo. Salah satu parameter minyak trafo adalah konstanta dielektrik. Berdasarkan IEC-60296, konstanta dielektrik minyak trafo berada pada rentang (2,1-2,2) pada frekuensi rendah dan untuk berbagai suhu (Shah, 2011). Studi tentang konstanta dielektrik minyak nabati sangat penting dilakukan untuk memberikan penyediaan alternatif minyak trafo dalam negeri dan untuk peningkatan nilai ekonomi minyak sawit.

Kualitas minyak nabati sawit sebagai pengganti alternatif minyak trafo dapat diketahui dengan mengukur sifat listriknya (konstanta dielektrik). Minyak goreng sawit juga mempunyai sifat listrik sehingga dapat digunakan sebagai bahan dielektrik. Setiap bahan memiliki sifat listrik yang khas dan besarnya sangat ditentukan oleh kondisi internal bahan tersebut, seperti momen dipol listrik, komposisi bahan kimia, kandungan air, keasaman dan sifat internal lainnya [1]. Sifat dielektrik bahan nabati dibutuhkan untuk memahami perilaku bahan ketika dimasukkan ke medan elektromagnetik pada frekuensi dan suhu tertentu. Konstanta dielektrik adalah ukuran kemampuan bahan menyimpan energi listrik [2].

Penelitian mengenai pengukuran sifat listrik pada minyak telah dilakukan oleh [3] yang melakukan pengukuran kapasitansi dengan menggunakan plat kapasitor sejajar dalam membuat sensor kualitas pada minyak dan didapatkan hasil bahwa sampel minyak goreng sebelum dipakai dan sesudah dipakai dapat dibedakan pada frekuensi $50 \mathrm{kHz}$. Sensor dan sistem rangkaian diperlukan untuk merubah suatu besaran fisik 
tertentu menjadi besaran listrik. Sensor kapasitif dalam rangkaian berfungsi untuk mendeteksi perubahan komposisi bahan dielektrik dengan menentukan nilai kapasitansi dan konstanta dielektrik. Adanya perubahan kapasitansi pada kapasitor pelat sejajar dapat diketahui dengan mengukur tegangan keluaran menggunakan osiloskop [4]. Penelitian mengenai pengukuran nilai konstanta dielektrik dengan menggunakan plat sejajar juga telah dilakukan oleh [5] pada oli dengan berbagai viskositas pada frekuensi (100-2000) Hz. Khaled et al

[6] juga melakukan penelitian tentang penurunan kualitas minyak goreng yang dilakukan dengan cara memanasan minyak goreng selama 30 jam.

Berdasarkan uraian-uraian diatas, perlu dilakukan penelitian yang bertujuan untuk mengetahui nilai konstanta dielektrik minyak nabati sawit, menggunakan rangkaian sederhana dan osiloskop. Pada penelitian ini sampel yang digunakan berasal dari minyak goreng curah dan kemasan. Perlakuan tambahan yaitu dengan pemanasan, setelah dipanaskan selama satu jam, setelah dipanaskan selama dua jam, dan setelah dipanaskan selama tiga jam. Pada penelitian ini rangkaian elektronik sederhana yang digunakan dari rangkaian IC Timer 555 dan osiloskop.

\section{METODOLOGI}

Penelitian ini dilaksanakan pada bulan Mei 2017 sampai September 2017 di Laboratorium Elektronika dan Instrumentasi Jurusan Fisika Fakultas Matematika dan Ilmu Pengetahuan Alam Universitas Jember. Ada beberapa tahapan yang dilakukan oleh peneliti untuk menyelesaikan penelitian ini sebagai rancangan penelitian. Rancangan penelitian ini disusun berdasarkan tahapan; studi literatur, persiapan alat dan sampel, pemberian perlakuan panas sampel, kalibrasi alat, pengambilan data, dan analisa data.

\section{Persiapan Sampel}

Sampel minyak nabati yang dipergunakan dalam penelitian ini diperoleh dari pasar lokal. Sampel terdiri dari minyak kemasan bermerk dan minyak curah. Pemanas dan termometer untuk memberikan perlakukan panas dan pengukur suhu. Masing-masing sampel dikondisikan suhunya pada $100{ }^{0} \mathrm{C}$ kemudian dibiarkan pada suhu tersebut hingga lama 1 jam, 2 jam dan 3 jam.

\section{Persiapan Rangkaian Elektronik dan Sensor}

Sensor kapasitif yang digunakan pada penelitian ini terbuat dari Printed Circuit Board (PCB) bahan tembaga membentuk pelat sejajar. Rangkaian elektronik pada PCB dan komponen tambanan, kapasitor 0,01 $\mu F$, resistor sebanyak 3 buah masing-masing $(100 \mathrm{k} \Omega, 22 \mathrm{k} \Omega$ dan $1 \mathrm{k} \Omega)$, IC Timer NE 555 sebagai komponen utama.

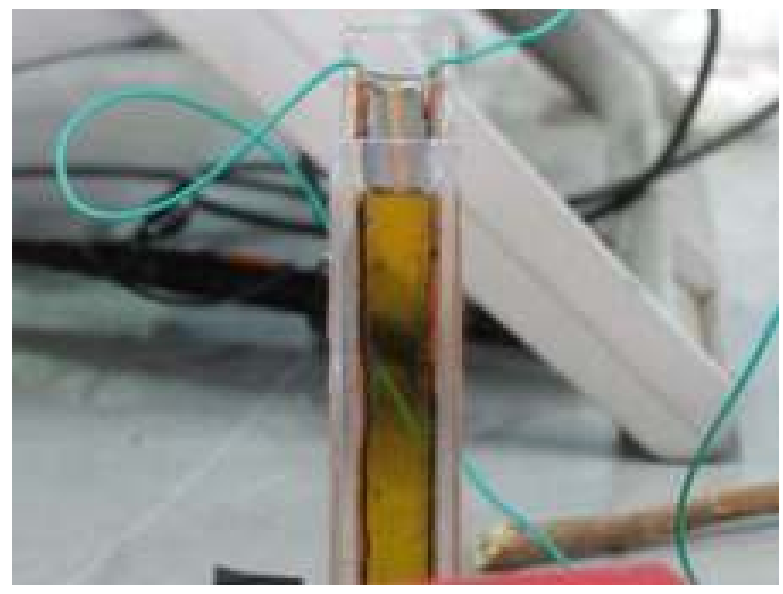

Gambar 1. Susunan pelat sejajar dan sebagai sensor kapasitif Cx 


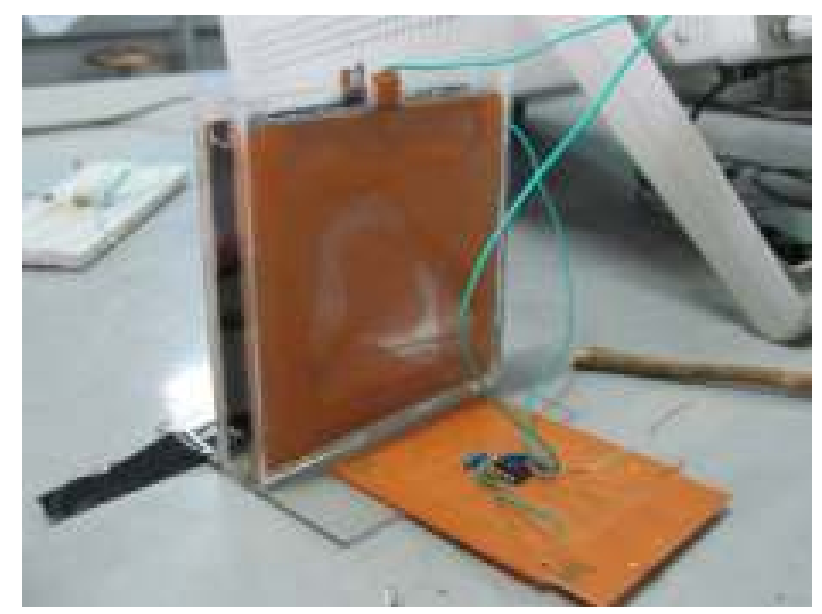

Gambar 2. Susunan alat sensor kapasitif

Bahan tambahan yang diperlukan; kabel, isolasi listrik, solder untuk menyambung komponen saat dirangkai. Alat ukur tambahan; osiloskop GW-Instek GOS-226G untuk periode melalui pengamatan gelombang output dari rangkaian. Sensor kapasitif $(\mathrm{Cx})$ terbuat dari pelat sejajar dari tembaga berukuran 10 $\mathrm{cm}$ x $10 \mathrm{~cm}$ dengan jarak antar pelat sebesar $1 \mathrm{~cm}$. Pelat sejajar tersebut dilapisi dengan isolator pada permukaan tembaga yang akan bersentuhan dengan sampel minyak goring (gambar 1).

Sebelum melakukan penyusunan rangkaian, sensor kapasitif yang telah dirangkai seperti pada gambar 2, diuji coba terlebih dahulu dan kemudian dikalibrasi. Setelah terbukti bekerja dengan baik kemudian semua alat disusun seperti pada gambar 2 berikut ini.

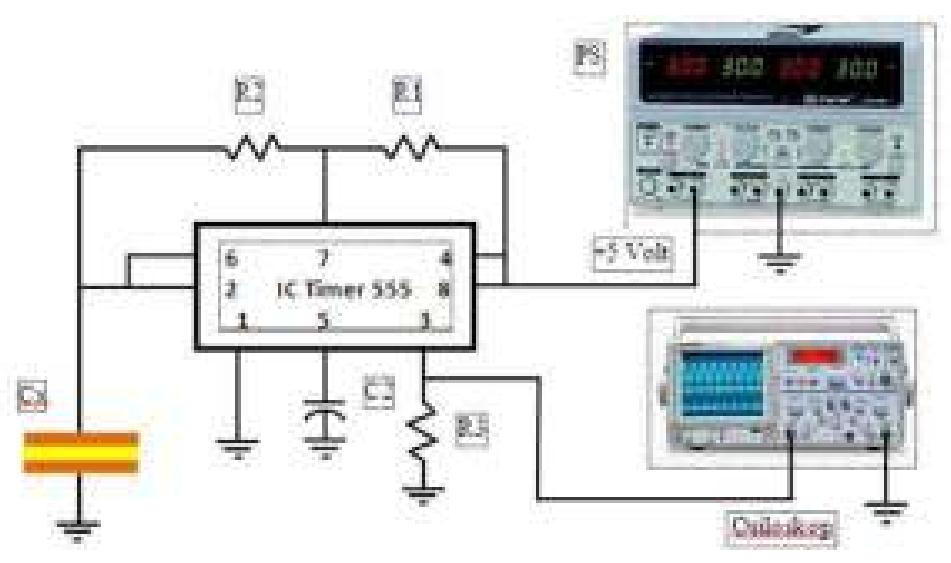

Gambar 3. Susunan rangkaian alat, sensor kapasitif, dan osiloskop

Keterangan gambar :

1. $\mathrm{Cx}$ : Kapasitor simulasi (sensor) dengan bahan dielektrik minyak goreng sebagai sensor.

2. $\mathrm{C} 2$ : Kapasitor $0,01 \mu \mathrm{F}$.

3. R1 : Resistor sebesar $100 \mathrm{k} \Omega$

4. R2 : Resistor sebesar $22 \mathrm{k} \Omega$

5. R3 : Resistor sebesar $1 \mathrm{k} \Omega$.

6. PS : Power Suply / Catu daya dengan tegangan sebesar +5 volt

7. Osiloskop untuk mengamati gelombang input dan output dari rangkaian 


\section{Perlakuan Sampel Minyak}

Pada penelitian ini sampel yang digunakan; 2 macam minyak nabati dari minyak goreng, yaitu minyak goreng curah dan minyak goreng dalam kemasan. Masing-masing minyak goreng akan dibagi menjadi 4 kelompok uji, yaitu :

Kelompok 1 : Minyak goreng tanpa perlakuan.

Kelompok 2 : Minyak goreng dengan perlakuan digoreng selama 1 jam dengan suhu $100^{\circ} \mathrm{C}$ dengan

Kelompok 3 : Minyak goreng dengan perlakuan digoreng selama 2 jam dengan suhu $100^{\circ} \mathrm{C}$ dengan fluktuasi yang diperbolehkan sebesar $20^{\circ} \mathrm{C}$.

Kelompok 4 : Minyak goreng dengan perlakuan digoreng selama 3 jam dengan suhu $100^{\circ} \mathrm{C}$ dengan fluktuasi yang diperbolehkan sebesar $20^{\circ} \mathrm{C}$.

Setelah kelompok sampel tersebut selesai diberi perlakuan yang berbeda, kemudian dibiarkan hingga suhunya kembali ke suhu ruang $\left(27^{\circ}-28^{\circ} \mathrm{C}\right)$. Tahap berikutnya adalah pengambilan data kapasitansi dan konstanta dielektrik sampel.

\section{Kalibrasi Alat Penelitian}

Kalibrasi alat dilakukan untuk mengetahui apakah desain alat percobaan dapat digunakan untuk mengukur nilai kapasitansi dan konstanta dielektrik. Langkah awal adalah mendesain alat seperti gambar 2 . Kalibrasi dilakukan dengan menggunakan aquades, apabila nilai konstanta dielektrik yang terukur sudah sama atau mendekati nilai konstanta dielektrik aquades yang didapatkan dari referensi yaitu 78 (pada suhu kamar), maka alat dan desain penelitian sudah bisa digunakan.

\section{Pengambilan Data}

Setelah semua alat selesai disusun seperti pada gambar 2, selanjutnya dilakukan tahap pengambilan data dengan menggunakan sensor kapasitif dan osiloskop. Dalam proses pengambilan data ini akan didapatkan nilai frekuensi $(f)$, melalui pengukutan perioda (T ) dengan bantuan osiloskop. Nilai frekuensi ini digunakan untuk menentukan nilai kapasitansi dari minyak goreng curah dan minyak goreng kemasan dengan menggunakan persamaan berikut:

$$
C=\frac{1,44}{f(R 1+2 R 2)}
$$

\section{Analisis Data}

Pada penelitian ini, nilai konstanta dielektrik diperoleh dari nilai kapasitansi yang akan didapatkan dengan menggunakan persamaan 3.4 berikut ini:

$$
\mathrm{c}=k \frac{z_{0} \mathrm{~A}}{\mathrm{~d}}
$$

maka nilai $k$ ditunjukan seperti pada persamaan 3.5 dibawah ini:

$$
k=\mathrm{c} \frac{\mathrm{d}}{\varepsilon_{0} A}
$$

Keterangan:

$k \quad:$ Konstanta dielektrik

$\varepsilon_{0}:$ Permitivitas ruang hampa $\left(8,85 \times 10^{-12} \mathrm{~F} / \mathrm{m}\right)$

A : Luas pelat $\left(\mathbf{m}^{2}\right)$

d : Jarak antar pelat $(\mathrm{m})$

Proses pengambilan data dilakukan pengulangan sebanyak 3 kali dan selanjutnya dari data-data yang diperoleh akan dianalisis untuk menentukan ralat nilai kapasitansi dari minyak goreng curah dan minyak goreng kemasan, dengan menggunakan standart deviasi: 


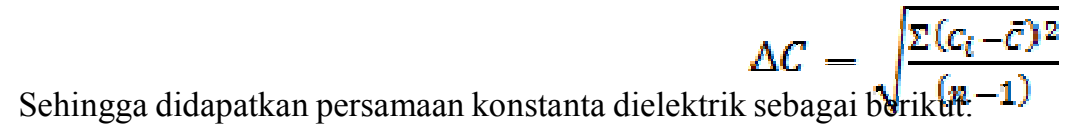

$$
c=(\bar{c} \pm \Delta C)
$$

Keterangan:

$\Delta G$ : Standart deviasi kapasitansi (farad)

$\widehat{C_{i}}$ : Nilai kapasitansi ke-I (farad)

$\bar{C}$ : Rata-rata nilai kapasitansi(farad)

$n \quad$ : Jumlah pengulangan

Begitu juga dengan nilai konstanta dielektrik dari minyak goreng curah dan kemasan, dari data yang diperoleh dapat ditentukan ralat nilai konstanta dielektriknya dengan menggunakan persamaan standart deviasi seperti berikut:

$$
\Delta k=\sqrt{\frac{\Sigma\left(k_{i}-\bar{k}\right)^{2}}{(n-1)}}
$$

Sehingga didapatkan persamaan konstanta dielektrik sebagai berikut:

$$
k=(\bar{k} \pm \Delta k)
$$

Keterangan:

$$
\begin{array}{ll}
\Delta \boldsymbol{k} & \text { : Standart deviasi konstanta dielektrik } \\
\boldsymbol{k}_{i} & \text { : Nilai konstanta dielektrik ke-i } \\
\bar{k} & \text { : Rata-rata nilai konstanta dielektrik } \\
n & \text { : Jumlah pengukuran }
\end{array}
$$

Nilai standart deviasi yang didapatkan dari persamaan 3.6 juga dapat digunakan untuk mengetahui tingkat ketelitian dari alat sensor kapasitif yang akan dibuat dan digunakan dalam penelitian ini. Analisa data yang dilakukan adalah mengetahui pengaruh lama pemanasan minyak goreng terhadap nilai kapasitansi dan konstanta dielektrik minyak goreng. Untuk itu akan ditampilkan data nilai kapasitansi dan konstanta dielektrik minyak terhadap lama pemanasan (pemanasan dalam jam) dalam grafik nilai kapasitansi terhadap lama pemanasan dan grafik nilai konstanta dielektrik terhadap lama penggunaan.

Analisa berikutnya digunakan untuk mengetahui perbedaan karakteristik kapasitansi dan konstanta dielektrik minyak goreng curah dan minyak goreng kemasan. Untuk hal itu akan ditampilkan data nilai kapasitansi dan konstanta dielektrik minyak goreng curah dan minyak goreng kemasan pada saat sebelum digunakan dan sesudah digunakan sebagai bahan penggorengan dalam bentuk grafik hubungan nilai kapasitansi terhadap jenis minyak (curah dan kemasan).

\section{HASIL DAN PEMBAHASAN (10 PT)}

Pengukuran awal dilakukan pada sampel 4 (empat) jenis minyak nabati (minyak goreng) yang terdiri dari 3 minyak kemasan berbeda dan 1 minyak goreng curah. Perlakuan masing-masing sampel berdasarkan lama pemanasan masing-masing dipanaskan selama 1 jam, dipanaskan selama 2 jam dan dipanaskan selama 3 jam. Pada saat pengukuran sampel minyak dimasukkan pada wadah yang sekaligus sebagai sensor kapasitif. Pengambilan data dilakukan dengan menghubungkan sensor kapasitif pada rangkaian multivibrator dan keluarannya dihubungkan ke osiloskop. Parameter yang diperoleh pada osiloskop adalah perioda gelombang keluaran. 
Hasil pengukuran perioda kemudian digunakan untuk menentukan nilai kapasitansi. Setelah didapat nilai kapasitansi, nilai konstanta dielektrik dapat ditentukan dengan persamaan 2. Berdasarkan persamaan tersebut nilai konstanta dielektrik proporsional terhadap nilai kapasitansi. Rosita [7] menyatakan bahwa nilai kapasitansi berbanding lurus dengan konstanta dielektrik, maka nilai konstanta dielektrik akan menurun jika nilai kapasitansi menurun. Hasil perhitungan nilai kapasitansi dan konstanta dielektrik pada minyak goreng kemasan $\mathrm{A}$, kemasan $\mathrm{B}$, kemasan $\mathrm{C}$ dan minyak goreng curah menunjukkan nilai kapasitansi dan konstanta dielektrik yang berbeda. Nilai rata-rata kapasitansi sebelum digunakan (pada suhu kamar, 27-28 ${ }^{\circ} \mathrm{C}$ ) yaitu Page $\mid 6$

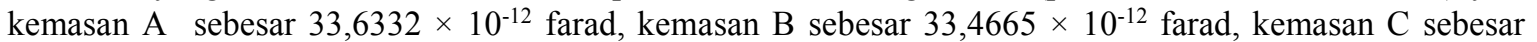
$34,2998 \times 10^{-12}$ farad, dan minyak goreng curah sebesar $35,1332 \times 10^{12}$ farad. Sedang nilai rata-rata konstanta dielektrik sampel sebelum dipanaskan (pada suhu kamar, 27-28 ${ }^{\circ} \mathrm{C}$ ) dari minyak kemasan A, kemasan B, kemasan $\mathrm{C}$ dan minyak goreng curah masing-masing 3,8004; 3,7815; 3,8757; dan 3,9699. Menurut [8] minyak sawit yang baik dapat dilihat dari sifat listriknya dan mempunyai nilai konstanta dielektrik 3,2 pada suhu ruang $\left(28^{\circ} \mathrm{C}\right)$. Perbedaan ini mungkin disebabkan oleh komposisi sampel yang digunaka sedikit berbeda. Sedang menurut hasil penelitian [9] tentang studi karakteristik minyak goreng kelapa sawit kemasan dengan metode dielektrik didapatkan hasil bahwa nilai konstanta dielektrik minyak goreng kelapa sawit kemasan berkisar antara 3,217-4,005. Berdasarkan hasil penelitian Wardani diatas terdapat kemiripan dengan hasil penelitian yang sedang dilakukan pada penelitian ini khususnya pada suhu kamar. Sedang nilai kapasitansi dan konstanta dielektrik minyak goreng curah lebih tinggi dibanding minyak goreng kemasan A, kemasan $\mathrm{B}$ dan kemasan $\mathrm{C}$, hal ini dimungkinkan karena perbedaan komposisi dari asam lemaknya. Menurut [10] bahwa minyak goreng curah mempunyai kadar asam lemak yang lebih tinggi dibandingkan dengan minyak goreng kemasan.

Pada suhu kamar (sebelum dipanaskan), nilai kapasitansi minyak goreng kemasan menunjukkan perbedaan. Minyak kemasan C memiliki kapasitansi tertinggi dibandingkan minyak kemasan A dan minyak kemasan B. Nilai kapasitansi minyak kemasan A jauh lebih rendah daripada minyak kemasan $\mathrm{C}$ yaitu $33,6332 \times 10^{-12}$ farad. Sedangkan nilai kapasitansi minyak goreng kemasan B adalah yang paling rendah yaitu 33,4665 x $10^{-12}$ farad. Ketiga minyak goreng kemasan tersebut memiliki nilai kapasitansi yang berbeda walaupun melalui proses penyaringan yang sama sebagai minyak goreng kemasan. Hal ini dimungkinkan karena adanya perbedaan komposisi dari minyak goreng kemasan A, kemasan B dan kemasan C berbeda. Hasil perhitungan kapasitansi dalam bentuk grafik minyak kemasan (A, B, dan C) minyak goreng curah dengan perlakuan lama pemanasan 1 jam, 2 jam dan 3 jam dapat dilihat pada gambar 3 berikut.

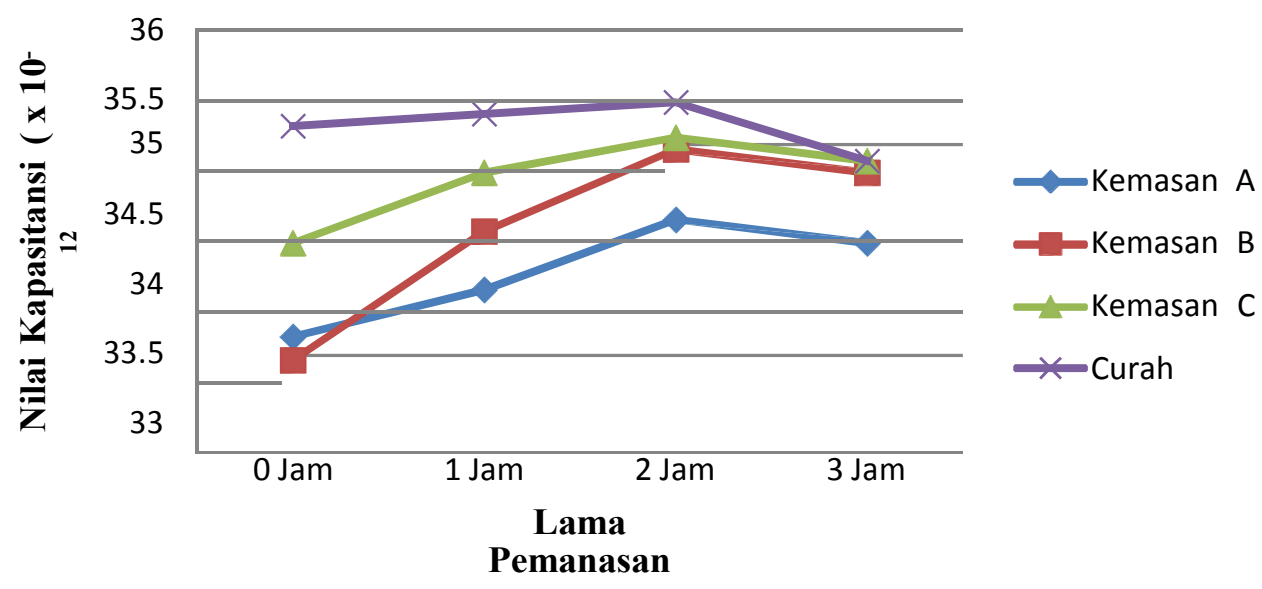

Gambar 3. Pengaruh lama pemanasan terhadap nilai kapasitansi minyak goreng curah dan kemasan

Dari gambar 3, nilai kapasitansi minyak yang diberi perlakuan dibanding minyak goreng dengan perlakuan lama pemanasan 1 jam cenderung mengalami kenaikan, pada lama pemanasan 2 jam mengalami kenaikan dan pada lama pemanasan 3 jam mengalami penurunan. Hal ini terjadi semua jenis minyak goreng kemasan (A, B dan C) dan minyak jenis curah. Penurunan nilai kapasitansi minyak goreng pada pemanasan 3 jam ini dimungkinkan karena adanya salah satu atau beberapa dari komposisi minyak goreng yang menguap seperti lemak jenuh, lemak tak jenuh dan vitamin ketika minyak sudah mengalami pemanasan 
selama 3 jam. Komposisi minyak goreng kemasan dapat dilihat pada lampiran G. Kenaikan dan penurunan nilai kapasitansi juga akan mempengaruhi nilai dari konstanta dielektrik yang dapat dilihat pada gambar 4 .

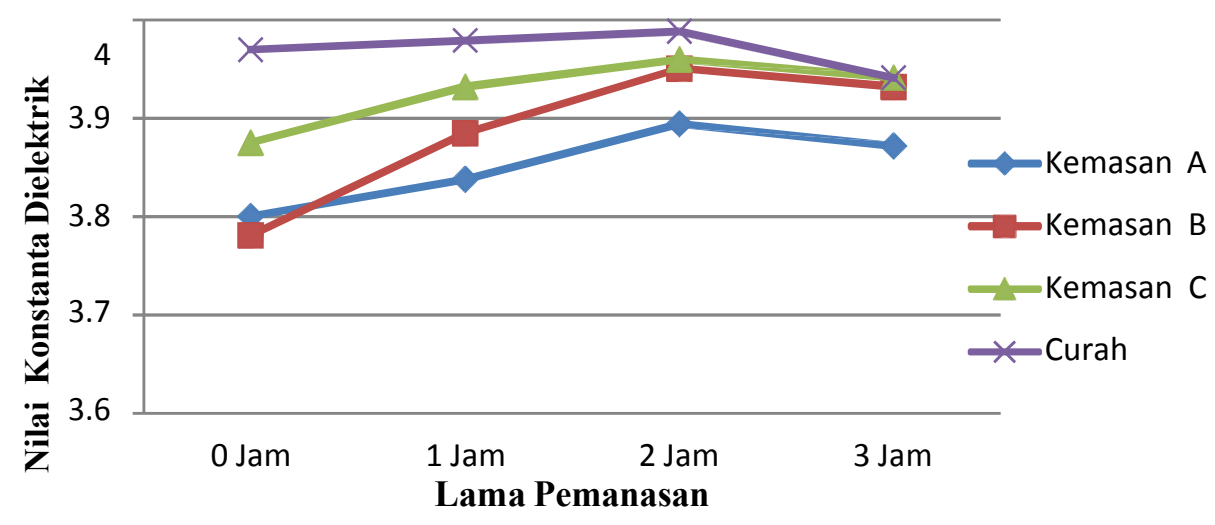

Gambar 4. Pengaruh lama pemanasan terhadap nilai konstanta dielektrik minyak goreng curah dan kemasan

Dari grafik tersebut dapat dilihat bahwa nilai konstanta dielektrik berbagai perlakuan dibandingkan dengan kontrol yaitu pada minyak goreng kemasan (A, B, dan C) dan minyak curah dengan lama pemanasan 1 jam, lama pemanasan 2 jam, mengalami kenaikan sedang pada lama pemanasan 3 jam mengalami penurunan. Perbedaan nilai konstanta dielektrik masing-masing minyak pada setiap perlakuan mungkin disebabkan oleh komposisi sedikit berbeda.

Pada minyak goreng kemasan A, perubahan nilai konstanta dielektrik dari kontrol sampai pemanasan 1 jam mengalami penambahan sebesar 0,0376. Perubahan nilai konstanta dielektrik dari pemanasan 1 jam sampai 2 jam mengalami penambahan sebesar 0,0565. Sedangkan perubahan dari pemanasan 2 jam sampai 3 jam mengalami penurunan sebesar 0,0225. Pada minyak goreng kemasan B, Perubahan nilai konstanta dielektrik dari kontrol sampai pemanasan 1 jam mengalami penambahan sebesar

0,1036. Perubahan nilai konstanta dielektrik dari pemanasan 1 jam sampai 2 jam mengalami penambahan sebesar 0,0659. Sedangkan perubahan nilai konstanta dielektrik pada pemanasan 2 jam sampai 3 jam mengalami penurunan sebesar 0,0188. Pada minyak goreng kemasan $\mathrm{C}$, perubahan nilai konstanta dielektrik dari kontrol sampai pemanasan 1 jam mengalami penambahan sebesar 0,0565.

Perubahan nilai konstanta dielektrik dari 1 jam sampai 2 jam mengalami penambahan sebesar 0,0282. Sedangkan perubahan nilai konstanta dielektrik dari pemanasan 2 jam sampai 3 jam mengalami penurunan sebesar 0,0188. Pada minyak goreng curah, perubahan nilai konstanta dielektrik dari kontrol sampai pemanasan 1 jam mengalami penambahan sebesar 0,0094. Perubahan nilai konstanta dielektrik dari pemanasan 1 jam sampai 2 jam juga mengalami penambahan sebesar 0,0094. Sedangkan perubahan nilai konstanta dielektrik pada pemanasan 2 jam sampai 3 jam mengalami penurunan sebesar 0,0469. Perubahan konstanta dielektrik minyak goreng curah pada setiap kenaikan lama pemanasan tidak berubah signifikan.

Menurut [11] yang melakukan penelitian pemanasan minyak selama 30 jam untuk melihat penurunan kualitas minyak goreng, secara keseluruhan didapatkan hasil bahwa kapasitansi dari minyak goreng mengalami kenaikan sesuai dengan lama pemanasan. Hal ini sesuai dengan hasil penelitian bahwa selama pemanasan 1 jam dan 2 jam cenderung meningkat, akan tetapi pada pemanasan selama 3 jam mengalami penurunan.

\section{KESIMPULAN}

Nilai konstanta dielektrik minyak goreng dari kelapa sawit sebelum dipanaskan dan setelah dipanaskan yaitu curah dalam rentang $(3,94-3,97)$, kemasan A sebesar (3,80-3,87), kemasan B sebesar (3,783 , 95) dan kemasan $\mathrm{C}$ sebesar $(3,93-3,97)$. Rata-rata dari semua sampel yang digunakan menunjukkan kenaikan nilai konstanta dielektrik pada saat dipanaskan. Berdasarkan persyaratan IEC-60296, maka perlu usaha menurunkan nilai konstanta dielektrik agar dapat digunakan sebagai minyak trafo. 


\section{ELKOM “Jurnal Teknik Elektro Dan Komputasi"}

Vol. 1, No. 1, Agustus 2019, Hal: 1-9

ISSN: , DOI: , Terakreditasi Dikti dengan SK:

\section{REFERENSI}

[1] Amang. 1996. Ekonomi Minyak Goreng di Indonesia. Bogor : IPB Press

[2] Arum, Z. H., C. S. Widodo. dan G. Saroja. 2015. Studi Pengukuran Nilai Konstanta Dielektrik Oli Berbagai Viskositas Pada Frekuensi 100 Hz-2000 Hz. Skripsi. Malang: Universitas Brawijaya.

[3] Beiser, A. 1962. The Mainstream Of Physics. London: Addison-Wesley Publishing Company, INC.

[4] Cahyono, B. E. 2007. Pengukuran Kapasitansi Kapasitor Menggunakan Calorimeter Dengan Sensor Suhu LM335. Jurnal saintifika 8(1) : 71-80.

[5] Cahyono, B. E., Misto. dan F. Hasanah. 2016. Karakterisasi Sensor Kapasitif Untuk Penentuan Level Aquades. Page 8 REM Jurnal 1(2). Jember: Universitas Jember.

[6] Darmawan, D. 2012. Pengenalan Osiloskop (CRO). Yogyakarta: Universitas Negeri Yogyakarta.

[7] Halliday, D dan R. Resnick. 1996. Fisika Jilid 2 Edisi Ketiga. Jakarta: Erlangga.

[8] Hermawan, B. 2005. Monitoring Kadar Air Tanah Melalui Pengukuran Sifat Dielektrik Pada Lahan Jagung. Jurnal Ilmu-Ilmu Pertanian Indonesia. 7. 15-22.

[9] Istigfaro, Nila. 2010. Peningkatan Kualitas Minyak Goreng Bekas Dengan Metode Adsorpsi Menggunakan Bentonit-Karbon Aktif Kelor (Moringa oliefera). Skripsi. Malang : UIN Malang

[10] Khaled, A. Y., S. A. Aziz dan F. Z. Rokhani. 2015. Capacitive Sensor Probe to Assess Frying Oil Degradation. Journal. Malaysia : Universiti Putra Malaysia.

[11] Ketaren, S. 1996. Pengantar Teknologi Minyak Dan Lemak Pangan. Jakarta: Universitas Indonesia. 
ELKOM “Jurnal Teknik Elektro Dan Komputasi”

Vol. 1, No. 1, Agustus 2019, Hal: 1-9

ISSN: , DOI: , Terakreditasi Dikti dengan SK:

\section{RIWAYAT HIDUP PENULIS (10 PT)}

\begin{tabular}{|l|l|}
\hline & $\begin{array}{l}\text { Misto adalah dosen tetap program studi Fisika Universitas Jember. Menyelesaikan S1 Teknik } \\
\text { Fisika FTI ITS, bidang Instrumentasi dan Kontrol, Pendidikan Pascasarjana ITB bidang Fisika, } \\
\text { dan ITS bidang Optoelektronika. Bidang penelitian yang dilakukan adalah Instrumentasi dan } \\
\text { Aplikasi Laser. }\end{array}$ \\
\hline & $\begin{array}{l}\text { Supriyadi adalah dosen tetap program studi Fisika Universitas Jember. Ketua Laboratorium } \\
\text { Fisika Modern dan Aplikasi Laser program.studi Fisika. Pendidikan Pascasarjana ITB } \\
\text { Bandung. Bidang penelitian yang ditekuni adalah Komputasi Geofisika. }\end{array}$ \\
\hline
\end{tabular}

